\title{
Prevention of falls to a lower level: evaluation of an occupational health and safety intervention via subsidies for the replacement of scaffolding ${ }^{1}$
}

\section{Dr. Juan Carlos Rubio-Romero}

Associate Professor

School of Industrial Engineering

C/ Dr. Ortiz Ramos, s/n 29071 Málaga (SPAIN)

Universidad de Málaga (SPAIN)

$+34951952538$

juro@uma.es

Jesús Antonio Carrillo-Castrillo

Industrial Engineer

Responsible for Occupational Safety Promotion Programs

Regional Government of Andalusia

Seville (SPAIN)

Dr. Alistair Gibb

Professor of Construction Engineering Management

School of Civil \& Building Engineering

Loughborough University (UK)

KEYWORDS: intervention studies, government subsidies, program effectiveness, accident prevention, accidental falls.

\footnotetext{
${ }^{1}$ Rubio-Romero, J.C.; Carrillo-Castrillo, J.A. \& Gibb, A.G.F. (2013) Prevention of falls to a lower level: evaluation of an occupational health and safety intervention via subsidies for the replacement of scaffolding", International Journal of Injury Control and Safety Promotion, DOI:10.1080/17457300.2013.838272, published online 11/10/12

www.tandfonline.com/doi/full/10.1080/17457300.2013.838272. https://dspace.lboro.ac.uk/2134/13459
} 


\section{ABSTRACT}

Objective: Evaluate the impact of a subsidy policy for construction companies in Andalusia (Spain), which enables them to acquire new scaffolds.

Methods: The rate of falls from scaffolds within the Andalusian construction sector in the period 2009 to 2011 was analysed. A randomized controlled trial was not possible as the subsidy was granted according to a public and competitive call. A quasi-experimental design based on an intervention group (subsidized companies) and a control group was chosen. Companies in the control group were selected from the social security census of companies in order to avoid selection bias.

Results: The subsidy policy has led to an overall $71 \%$ decrease in the rate of accident involving falls to a lower level in the companies which received grants in the period 2009-2011. The confidence interval for the comparison for the before-after difference in rates between the intervention group and the control group is found significant (confidence 95\%, $\mathrm{p}=0.05$ ).

Conclusions: The improvement of scaffolds was effective in reducing rates of accident with falls to a lower level. This intervention should be a priority in public policies. The process of standardisation of equipment with high accident risk should be developed further.

\section{WHAT THIS PAPER ADDS}

Scaffolds are one of the most prevalent agents in falls to a lower level.

- Evidence provided on the effectiveness of scaffold updating (in line with EU bills).

Incidence rate of subsidized companies decreases after intervention.

The process of standardisation or technical specification of equipment with high accident risk should be developed further. 


\section{INTRODUCTION}

The occupational accident rate in Spain is one of the highest in Europe.[1] According to the EUROSTAT data, Spain had the second highest accident rate in 2007 in the construction industry (8.09), only just below Luxembourg (8.15).[2] The most common construction risk is falling to a lower level (55.8\% of accidents [3]) which is usually accompanied by one of the highest rates of serious or fatal outcomes. Scaffolds are one of the material agents most frequently involved in falls to a lower level. According to Camino López et al.,[4] the chances of an accident having serious consequences increases when scaffolds are involved.

Recently, the first two Andalusian Working Conditions Surveys have identified the risk of falling to a lower level as a serious concern for the construction workers. In the first one, performed in 2008 , this risk was identified by $56.2 \%$ of the construction workers surveys whereas in the second, performed in 2011, that proportion was of $45.9 \%$. [5, 6]

A report by the UK Health and Safety Commission in 2010 [7] presents the results of an analysis of all the falls to a lower level that took place in the UK in the period 2002-2008. It states that scaffolds are the third most dangerous material agent; both in terms of fatal and serious accidents, after ladders and roofs which are in first and second positions respectively (see Figures 1 and 2). Cutlip et al. indicate that the most frequent injuries of scaffold erectors were those due to physical strain and falls from scaffolds.[8, 9]

\section{Figure 1}

Figure 2

Consequently, it is not surprising that the improvement of the safety of scaffolds has been a priority issue in the intervention policies. Reasons for the applying innovation for scaffolding work also include the improvement of the ergonomic conditions. [10] The labour administration both in Spain and particularly in Andalusia has promoted the updating of scaffolds by companies using subsidies as financial inducements and also targeted safety consultation.[11]

The subject of this research is the subsidized updating of scaffolds in Andalusia which entails the replacement of non-certified scaffolds with EU certified scaffolds. The use of scaffolds compliant with the EU norm was not compulsory in Spain nor, consequently, in Andalusia, but the higher level of safety of the scaffolds compliant with the EU norm could not be ignored. Indeed, prior to the approval of the subsidies, the results obtained in the inspection of the technical conditions of scaffolds had been used to evaluate the security level.[12, 13] The study identified the lack of a guardrail as the most frequent deficiency in non-certified scaffolds. Obviously, the lack of a guardrail is directly related to the risk of accident in the form of falls to a lower level, usually with serious consequences. Thus, the main aim of the incorporation of standardised scaffolds was the prevention of falls to a lower level. The rest of the accidents where scaffolds are involved, such as during the assembly or dismantling of scaffolds or access to scaffolds, were only a secondary aim of the intervention.

Andalusia is the most populous and the second largest in area of the regions in Spain, with 8 provinces and a total area of over $87,268 \mathrm{~km}^{2}$ and more than 8.5 million inhabitants. The area of Andalusia, consequently, is larger than that of countries such as Belgium, the Netherlands, Denmark, Austria or Switzerland, and almost equivalent to that of Portugal. In demographic terms, the population of Andalusia is larger than that of Denmark, Switzerland and equal to that of Austria.

The subsidy programmes entailed not only the replacement of non-compliant scaffolds, but also their disposal.[14] The subsidies for the renewal of scaffolds was one of the initiatives included in the Plan General de Prevención de Riesgos Laborales in Andalusia,[15] as part of the funding grants for Small and Medium-sized Enterprises (SMEs). The subsidies were for the acquisition of standardised and certified scaffolds compliant with the norms UNE 76502:1990 [16] (equivalent to HD-1000:1988) or UNE EN 12810-1:2005 [17] (equivalent to EN128101:2003). The value of the grants was up to $€ 18,000$ with a maximum financing percentage of $45 \%$. During the implementation of the programme 598 grants were given in 2006, 428 in 2007, 378 in 2008 and 187 in 2009. The subsidies for the replacement of scaffolds had a public contribution of $€ 6,527,914.07$ and a global budget of investment of $€ 14,669,554$.69. The average percentage of the subsidy was $44.49 \%$, with an average subsidy per company of $€$ 
$4,649.51$ and an average budget for each investment project of $€ 10,448.40$. The number of participating companies was estimated at $5 \%$ of the registered SMEs in the construction sector.

Accurate estimation of the efficiency of the provision of public funds is very important.[18, 19] For this reason, despite the apparent technical improvement in the programme, the evaluation of the intervention was of great importance. Intervention studies, like this, can find whether or not interventions at the worksites have the desired effect.[20]

Another increasingly important issue is also the correct understanding of the decisionmaking process and the improvement of the design of the subsidy programmes to make them not only efficient but also attractive for the decision makers.[21] The EU is also interested in this question because the need for a greater understanding of the effectiveness of economic incentives to promote occupational safety and health (OSH) is mirrored in the new European OSH strategy, in particular as regards small and medium-sized enterprises.[22]

The subjective level of satisfaction of the companies targeted by this subsidy policy has already been dealt with in a previous study which involved a poll among the managers of the companies which asked for a subsidy.[23] The results of the qualitative analysis provided by the poll revealed a positive general response to the subsidy programme. Up to $89 \%$ of the managers thought that the investment was efficient or very efficient and $87 \%$ said that it had actually improved the working conditions in the company or would have done so. Most companies answered that the incentive programme was a good idea: $92 \%$ of the companies claimed that the lack of economic resources is a serious obstacle for a prevention policy, and $94 \%$ considered that the grants were necessary.

However, for an accurate evaluation of the impact of these interventions with public money it is not only necessary to estimate the subjective perception or opinion of the target companies but it is also important to make a rigorous analysis and measurement of the efficiency obtained in relation to the goals. In the technical literature there is agreement on the different methodologies and their implementation for the evaluation of this kind of interventions.[24, 25] Previous studies on the design of incentives for SMEs insist that one of the difficulties for a correct evaluation is the low number of accidents recorded in any case.[23]

Up to now there have not been any studies on the efficiency of the subsidies for the incorporation of scaffolds compliant with EU norms. There are a number of investigations which have focussed on the evaluation of interventions in health and safety.

As regards interventions involving scaffolds, there was a campaign in Finland in the shipbuilding industry [26] to raise the risk consciousness of scaffold workers. The campaign successfully reduced the number of work accidents by $39 \%$ in the intervention area. Recently, the effect of regulations in reducing construction injuries has been also analyzed.[27]

By means of autoregressive analyses, Yassin et al.,[28] examined the efficiency of a compulsory provision concerning scaffold safety standards in the construction industry in the USA. According to their analysis, 4.6 fatal accidents, 404 non-fatal accidents and 2,896 workday losses per year were prevented. In addition, building companies saved US\$5.8 million per year. Although these results seemed to indicate the efficiency of the legal change introduced in relation to the use of norm-compliant scaffolds, the study did not check, at company level, either the impact of the replacement of scaffolds nor the possible relationship between scaffold replacement and decrease in the number of accidents. Thus, other simultaneous actions may have biased the real impact of scaffold replacement. On the other hand, the legal provisions affected the construction sector as a whole, whereas the interventions dealt with in our study are directed at a restricted number of companies.

This research is focussed on the evaluation, at company level, of the decrease in the rate of accidents caused by falls to a lower level as a result of the incorporation of EU-compliant scaffolds in Andalusia.

In the period studied, from 2009 to 2011, the construction sector in Andalusia is quite stable in terms of work load and types of building contracted (see Table 1).[29] 
Table 1. Number of licences of construction in Andalusia

\begin{tabular}{lccc}
\hline License type & $\mathbf{2 0 0 9}$ & $\mathbf{2 0 1 0}$ & $\mathbf{2 0 1 1}$ \\
\hline New buildings construction & & & \\
0-1 stories & 5,396 & 4,774 & 3,784 \\
2 or more stories & 9,538 & 8,859 & 7,569 \\
Enlargements & 1,101 & 867 & 884 \\
Alterations & 7,234 & 6,347 & 5,208 \\
Reinforcements & 288 & 280 & 321 \\
\hline
\end{tabular}

Source: INE (Spanish National Institute of Statistics). This data is available in http://www.ine.es (accessed in July 2013).

\section{METHOD}

After the implementation of the intervention programme, the Consejo Andaluz de Prevención de Riesgos Laborales, a consulting tripartite body for prevention policies for the Andalusian labour authority, requested the evaluation of the efficiency of the programme.

The aim of the research was to analyse the impact of the changes introduced by these subsidies on the accident rate at company level while, at the same time, keeping in check any possible biasing factor. The ideal thing to do would have been to carry out an experiment for this purpose,[30] However, where public policies are concerned, researchers cannot randomly select the companies that are granted a subsidy.

After examining the different methodologies available for the evaluation of the efficiency of this intervention in the field of health and safety, a quasi-experimental design based on a case group and a control group was chosen.[24, 25]

It must be born in mind that the selection of the companies taking part in the programme may already be biased. On the one hand, it is clear that these companies are interested in and committed to work risk prevention and on the other, they have a high risk of scaffold accidents. Probably, other companies within the same economic ranking do not use scaffolds and, therefore, do not have this kind of accidents.

Another selection bias, very common in studies based on accident records, has to do with the fact that companies with no reported accidents are never included. Many SMEs have not reported any accidents during the years of the study. To avoid this bias, companies were selected from the census of companies in the Social Security System which is mandatory in Spain for all companies with at least one employee.[31]

Companies with employees in the period 2009-2011 were identified as candidates for the study, whether they had reported accidents or not. In Europe there is a Statistical Classification of Economic Activities (NACE). All candidates for the control group had a 41 as the code of statistical classification of economic activities in the European Community [32]. This code is used for building construction activities and it was the most frequent among the subsidized companies for renewing scaffolds.

For comparative purposes, 2009 was used as the baseline year and 2011 as the postintervention period. The method used is described in Robson et al. [33] for comparing the prepost rate changes in two groups using rate differences. The statistical test for the difference between the two rates differences is based in the calculation of the $z$-value (see equation 1 ) and the comparison with the Normal distribution. If $z$-value is smaller than 1.96 , the hypothesis of a different change in rates between both groups cannot be rejected with $95 \%$ confidence. 


$$
Z=\left(R D_{i}-R D_{c}\right) / S E
$$

$R D_{1}$ and $R D_{2}$ are the differences in rates in the intervention and control groups respectively

$\mathrm{SE}$ is the standard error (see equation 2).

$$
S E^{2}=A_{i 1} / S_{i 1}{ }^{2}+A_{i 2} / S_{i 2}{ }^{2}+A_{c 1} / S_{21}{ }^{2}+A_{c 2} / S_{c 2}{ }^{2}
$$

$A_{i 1}$ number of accidents in the intervention group before the intervention

$A_{i 2}$ number of accidents in the intervention group after the intervention

$A_{c 1}$ number of accidents in the control group before the intervention

$A_{c 2}$ number of accidents in the control group after the intervention

$S_{i 1}$ number of workers in the intervention group before the intervention

$S_{i 1}$ number of workers in the intervention group after the intervention

$\mathrm{S}_{\mathrm{c1}}$ number of workers in the control group before the intervention

$\mathrm{S}_{\mathrm{c} 1}$ number of workers in the control group after the intervention

The labour authority provided not only the names of the subsidized companies but also information on the accidents of falls at height. It was also recorded whether the company in question had received a subsidy for the replacement of scaffolds in 2009. The intervention group only includes companies subsidized in 2009 for the replacement of scaffolds and the control group only includes companies with no subsidy for replacement of scaffolds in 2009. The information was collected and anonymised before the analysis.

All the accidents with at least one day off work were considered, but not in itinere accidents (on the way to or from the workplace) or relapses. Falls to a lower level were accidents coded as such under the deviation code 51 in the ESAW-III methodology [34] and were included in the official workplace accident report in Spain.[35]

\section{RESULTS}

\section{General development of the accidents rate in the construction sector of Andalusia.}

The accident rates in the construction sector of Andalusia remained quite stable in the period (see Table 2). In addition, the proportion of accidents to a lower level to the total number of accidents did not change significantly from 2009 to 2011.

Table 2. General development of accidents in the Construction Sector of Andalusia

\begin{tabular}{lccc}
\hline Data & $\mathbf{2 0 0 9}$ & $\mathbf{2 0 1 0}$ & $\mathbf{2 0 1 1}$ \\
\hline No. of accidents from falls to a lower level & 1,092 & 835 & 746 \\
Staff (data from the Social Security census) & 208,230 & 172,741 & 145,707 \\
$\begin{array}{l}\text { Incidence rate of accidents to a lower level } \\
\text { (x100,000) }\end{array}$ & 524.4 & 483.4 & 512.0 \\
$\begin{array}{l}\text { Confidence interval of accidents to a lower } \\
\text { level (x100,000) }\end{array}$ & $493.3-$ & $450.6-$ & $475.3-$ \\
\hline
\end{tabular}

Source: authors' calculations based on the accidents reported to the labour authority of Andalusia and number of workers in the Social Security 

Development of the accident rate of falls to a lower level in the control and the
intervention groups.

6,201 candidate companies were suitable for our study, that is, companies with registered social security information for 2009 and 2011 and employing from 10 to 249 workers and without any subside for scaffolds. Of these, 179 received a subsidy for the replacement of scaffolds in 2009 (intervention group) and 6,022 received no subsidy (control group).

Table 3. Development of accidents by falls to a lower level in the intervention group

\begin{tabular}{lcccc}
\hline Data of the intervention group & $\mathbf{2 0 0 8}$ & $\mathbf{2 0 0 9}$ & $\mathbf{2 0 1 0}$ & $\mathbf{2 0 1 1}$ \\
\hline No. of accidents from falls to a lower level & 14 & 15 & 4 & 3 \\
Staff (data from the Social Security census) & 958 & 903 & 741 & 614 \\
$\begin{array}{l}\text { Incidence rate of accidents at height } \\
(\mathrm{x} 100,000)\end{array}$
\end{tabular}

Source: authors' calculations based on the accidents reported to the labour authority of Andalusia and number of workers in the Social Security census.

Table 4. Development of accidents by falls to a lower level in the control group

\begin{tabular}{lcc}
\hline Data of the control group & 2009 & 2011 \\
\hline $\begin{array}{l}\text { No. of accidents caused by falls to a lower } \\
\text { level }\end{array}$ & 244 & 230 \\
Staff (data from the Social Security census) & 57,116 & 44,005 \\
$\begin{array}{l}\text { Incidence rate of accidents at height } \\
(x 100,000)\end{array}$ & 427.2 & 522.7 \\
\hline
\end{tabular}

Source: authors' calculations based on the accidents reported to the labour authority of Andalusia and number of workers in the Social Security census with NACE economic classification code equal to 41.

As can be seen in Table 3, the accident rate concerning falls from scaffolds in the control group grown by 95.5 during the period 2006-2008, whereas the improvement in the intervention group

the rate descended by 1172.5 (see Table 4). The difference between these two figures is 1268.0.

Using the methodology suggested by Robson et al.,[33] for comparing the pre-post rate changes in two groups using rate differences, the confidence interval for the differences in the improvement in the accident rate observed between the control group and the intervention group, with a confidence level of $95 \%$, is significant with $p=0.05$ (258.1; 2,277.9). Consequently, it can be affirmed that, with that confidence level, the intervention had positive effects in the intervention group and that the effect is significant compared to the control group (see Table 5).

Table 5. Confidence intervals for differences in injury rates based on Robson et al. [32]

\begin{tabular}{lcc}
\hline Difference in rates & Lower & Upper \\
\hline Intervention group & 166.3 & $2,178.7$ \\
Control group & -181.7 & -9.2 \\
Difference between intervention and control group & 258.1 & $2,277.9$ \\
\hline
\end{tabular}

Note: A positive difference means that there is a reduction for injury rates from 2009 to 2011. 


\section{DISCUSSION}

A comparative analysis of the period 2009-2011 reveals that the measures implemented as part of the Plan General de Prevención de Riesgos Laborales in Andalusia successfully reduced the comprehensive incidence rates.

To evaluate the effectiveness of the intervention, a case-control design was chosen because an experimental design is not feasible in public interventions. The request depends on a decision made by the company and the granting of the subsidy is subject to an administrative procedure beyond the control of the researchers.

The use of a control group requires the definition of groups of companies as similar as possible.[33] For that reason, the industrial sector and the size of the company were used. Unfortunately, exposure to risk, i.e., the number of employees working with scaffolds could not be controlled. This study implements a selection of controls based on the census of companies.

Nevertheless, other threats to internal validity need to be considered. Regarding possible macro changes in the sector as a whole, the exposure to the risk of falling to a lower level seems to be perceived similar in the period [5,6] and the general development of accidents in the sector did not show any changes in the pattern or the rates of accidents to a lower level. At the same time, the number of building authorizations conceded in the period is very similar so little changes can be attributed in terms of work load. Moreover, the increase of the proportion of new buildings licences with two or more stories shows that the risk of falling to a lower level has increased in those companies remaining in business in 2011. In addition, it can be expected that the companies subsidized would contract buildings with two or more stories as they have invested in scaffolds recently.

For all those reasons, it is reasonable to assume that the exposure to risks of falling to a lower level did not change in the period, neither in the sector nor in the control group or the intervention group. In fact, the only significant change is observed in the intervention group, where the accident rates drops to a similar rate of accidents to a lower level observed in the construction sector as a whole and in the control group of enterprises in particular. One possible explanation is that the renewing of the scaffolds allowed the subsidized companies meet the same safety levels of the majority of the construction sector in Andalusia.

The initial incidence rate of falls to a lower level of the subsidized companies is higher than the incidence rate in the sector. This is easy to explain as the companies that ask for subside usually are those that uses scaffolds and that have experienced accidents recently. In addition, once the new scaffolds were incorporated, the rate of accidents to a lower level in the subsidized companies drop to the mean rate of the sector.

By doing this, selection bias typical of studies based only on accident records was avoided. In this manner, the study also includes companies with no accidents during the study period.

Inevitably, there was a lot of relevant information which was not available. It is not known whether non-subsidized companies already had certified scaffolds or whether they had replaced their scaffolds without subsidies. However, the study does allow us to draw relevant conclusions as to whether subsidized companies improved more than non-subsidized companies.

The confidence interval is quite broad, testifying the difficulty in finding enough evidence in this kind of interventions on account of the fortunately low number of accidents registered.[36]

Although previous studies showed evidence of the effectiveness of other interventions,[27, 36, 37, 38, 39, 40] this is the first available analysis of the effectiveness of renewing the scaffolds in construction enterprises in order to incorporate standardized ones.

The improvement observed in subsidized companies is significant enough to affirm that the programme was efficient.

Other studies [27, 39] have confirmed that compliance with certain new legal provisions significantly reduces the number of work accidents. In particular, in 2006, a new regulation on subcontracting in the construction sector was introduced in Spain. However, there is no reason to think that other control measures have biased the accident rate observed in our two groups considering the selection process adopted. 


\section{CONCLUSIONS}

The first conclusion to be drawn is that this incentive programme should be continued, since the Plan General para la Prevención de Riesgos Laborales in Andalusia led to a decrease in the accidents from falls to a lower level in the subsidized construction companies in the period 2009-2011. Furthermore, comparing to a control group, the decrease is significant.

On the other hand, the standardisation process or technical specification of equipment with high risk of accident must be further developed. This study has confirmed the positive effect of the changes introduced in the legal provisions concerning working platforms at height and manufactured under the UNE-EN 12810-11 standard. However, other equipment such as stepladders, for example, is equally important in the question of falls to a lower level.

This study identifies a specific kind of accidents and a control group by using the census of Social Security System. The use of these data bases is highly recommendable, because it avoids possible selection biases.

There are no similar studies on the evaluation of the efficiency of interventions for the updating of scaffolds where this equipment is viewed as a source of accidents from falls to a lower level. Therefore, this paper could contribute significantly to the design of future incentive programmes or to the improvement of those which have already been implemented.

\section{ACKNOWLEDGMENTS}

The authors acknowledge the Labour Authority of Andalusia and the construction companies taking part in the study for their help and collaboration.

\section{REFERENCES}

[1] Gestal-Otero JJ, Dominguez de la Calle M., Takkouche B. Occupational health in Spain. Int Arch Occup Environ Health;1999;6;345-350.

[2] Eurostat, 2012. European Commission. Your key to European Statistics. Available in

http://epp.eurostat.ec.europa.eul (accessed in May 2013).

[3] Instituto Nacional de Seguridad e Higiene en el Trabajo, 2012: Índices de incidencia de los accidentes de trabajo con baja en jornada de trabajo por sector y gravedad. Periodo junio 2011 - mayo 2012, respecto a junio 2010 - mayo 2011. Available in http://www.insht.es (accessed in May 2013).

[4] Camino López MA, Ritzel DO, Fontaneda I, González Alcantara OJ. Construction industry accidents in Spain. J Safety Res 2008;39;497-507.

[5] Instituto Andaluz de Prevención de Riesgos Laborales, 2009. I Encuesta Andaluza de Condiciones de Trabajo. Available in http://juntadeandalucia.es/

[6] Instituto Andaluz de Prevención de Riesgos Laborales, 2012. II Encuesta Andaluza de Condiciones de Trabajo. Available in http://juntadeandalucia.es/

[7] Health and Safety Commission. Statistics of workplace fatalities and injuries, falls to a lower level. UK: Health and Safety Commission 2010.

[8] Cutlip R, Hsiao H, Garcia R, Becker E, Mayeux B. A comparison of different postures for scaffold end-frame disassembly. Appl Ergon 2000;31;507-513.

[9] Cutlip R, Hsiao H, Garcia R, Becker E, Mayeux B Optimal hand locations for safe scaffoldend-frame disassembly. Appl Ergon 2002;33;349-355.

[10] de Jong AM, van der Molen H, Vink P, Eikhout S, Koningsveld, E. Reasons for Applying Innovations for Scaffolding Work. Int J Occup Saf Ergon 2003;9;161-175.

[11] Benavides FG, Rodrigo F, García AM et al. Evaluación de la efectividad de las actividades preventivas (Planes de Actuación Preferente) sobre la incidencia de las lesiones traumáticas no mortales con incapacidad laboral por accidentes de trabajo en jornada en España (1994-2004). Rev Esp Salud Publica 2007;6;605-624. 
[12] Rubio-Romero JC, Rubio Gámez MC, Carrillo-Castrillo JA. Analysis of the safety conditions of scaffolding on construction sites. Saf Sci 2013;55,160-164.

[13] Rubio-Romero J, Rubio M, García-Hernández C. Analysis of construction equipment safety in temporary work at height. Journal of Construction Engineering and Management 2013;139;914.

[14] Regional Government of Andalusia. Orden de 8 de mayo de 2006, por la que se establecen las bases reguladoras de la concesión de subvenciones por la Consejería de Empleo a microempresas, pequeñas y medianas empresas (PYME) que realicen proyectos e inversiones en materia de prevención de riesgos laborales. Boletín Oficial de la Junta de Andalucía 2006;106;5-17.

[15] Regional Government of Andalusia. Plan General para la Prevención de Riesgos Laborales en Andalucía, aprobado por Decreto 313/2003, de 11 de noviembre. Boletín Oficial de la Junta de Andalucía 2004;22;2768-2787.

[16] AENOR. UNE 76502:1990. Service and working scaffolds made of prefabricated elements. Material, dimensions, design loads and safety requirements. Madrid (Spain): Aenor 1990.

[17] AENOR. UNE EN 12810-1:2005. Façade scaffolds made of prefabricated components Part 1: Products specifications. Madrid (Spain): Aenor 2005.

[18] Geoff W, Urvashi P. Linking HSE activities to health and safety outcomes: A feasibility study. Research Report $n^{\circ}$ RR913. UK: Health and Safety Executive 2012.

[19] Habicht JP, Victora CG, Vaughan JP. Evaluation designs for adequacy, plausibility and probability of public health programme performance and impact. Int J Epidemiol 1999;28;10-18.

[20] Kristensen TS. Intervention studies in occupational epidemiology. Occup Environ Med 2005;62:205-210

[21] Kankaanpää E. Economic incentives as a policy tool to promote safety and health at work. Scand J Work Environ Health 2010;36;319-24.

[22] Elsler D, Treutlein D, Rydlewska I et al. A review of case studies evaluating economic incentives to promote occupational safety and health. Scand J Work Environ Health 2010;36; 289-298.

[23] Carrillo JA, Onieva L, Frutos C. Evaluación de un programa de subvenciones para la mejora de la seguridad y salud laboral de las PYMES en Andalucía. Arch Prev Riesgos Labor 2012;15;185-191.

[24] Shannon HS, Robson LS, Guastello SJ. Methodological criteria for evaluating occupational safety intervention research. Saf Sci 1999,31;161-179.

[25] Goldenhar LM, LaMontagne AD, Katz $T$ et al. The Intervention Research Process in Occupational Safety and Health: An Overview from the National Occupational Research Agenda Intervention Effectiveness Research Team. J Occup Environ Med 2001;43;616-622.

[26] Saarela KL. A poster campaign for improving safety on shipyard scaffold. J Safety Res 1989;4;177-185.

[27] Farina E, Bena A, Pasqualini $O$ et al. Are regulations effective in reducing construction injuries? An analysis of the Italian context. Environ Med 2005;62;830-835.

[28] Yassin,AS, Martonik JF. The effectiveness of the revised scaffold safety standard in the construction industry. Saf Sci 2004;42;921-931.

[29] Ministerio de Fomento: Anuario de la Construcción. Available in http://www.mfom.es (accessed in July 2013).

[30] Hogg-Johnson S. Robson L, Cole DC et al. A randomised controlled study to evaluate the effectiveness of targeted occupational health and safety consultation or inspection in Ontario manufacturing workplaces. Occup Environ Med 2012;69:890-900.

[31] Spanish Parliament. Real Decreto Legislativo 1/1994 por el que se aprueba el Texto Refundido de la Ley General de la Seguridad Social. Boletín Oficial del Estado 1994;154;20658-20708. 
[32] Robson LS, Shannon HS, Goldenhar LM et al. Guide to valuating the Effectiveness of Strategies for Preventing Work Injuries: How to Show Whether a Safety Intervention Really Works. USA: National Institute for Occupational Safety and Health 2001.

[33] European Communities. Nace Rev.2. Statistical classification of economic activities in the European Community. Luxembourg: Office for Official Publications of the European Communities 2008.

[34] European Commission. European Statistics on Accidents at Work (ESAW) - Methodology (ed. 2001). Luxembourg: Office for Official Publications of the European Communities 2002.

[35] Spanish Government. ORDEN TAS/2926/2002, de 19 de noviembre, por la que se establecen nuevos modelos para la notificación de los accidentes de trabajo y se posibilita su transmisión por procedimiento electrónico. Boletín Oficial del Estado 2002;279;40988-41013.

[36] Van der Molen HF, Lehtola MM, Lappalainen J et al. Interventions for preventing injuries in the construction industry. Cochrane Summaries. Available in http://summaries.cochrane.org/ (accessed in May 2013).

[37] Wickizer TM, Kopjar B, Franklin G et al. Do Drug-Free Workplace Programs Prevent Occupational Injuries? Evidence from Washington State. Health Serv Res 2004;39;91-110.

[38] Williams Jr Q, Ochsner M, Marshall E et al. The impact of a peer-led participatory health and safety training program for Latino day laborers in construction. J Safety Res 2010;41;253261.

[39] Nelson NA, Kaufman J, Kalat J et al. Falls in construction: injury rates for OSHA-inspected employers before and after citation for violating the Washington State Fall Protection Standard. Am J Ind Med 1997;31;296-302.

[40] Hasana A, Jhaa KN. Safety incentive and penalty provisions in Indian construction projects and their impact on safety performance. Int J Inj Contr Saf Promot 2013;20;3-12. 